\title{
Evidences of active and ancient Volcanism on Mars.
}

\section{A review $(*)$}

\author{
P. Hénervári (**)
}

Received on May 19th. 1972

Summar. - Since the end of the last Century some observations concerning flare-phenomena on Mars were reported by different explorers. According to the opinion of Heuseler $\left({ }^{11,}{ }^{12,13}\right)$, Katterfeld $\left({ }^{14}\right)$, Salieki $\left({ }^{15}\right)$, Sato $\left({ }^{16}\right)$ and other authors, the respective light-phenomena might have been the signs of active volcanoes on the planet. Grey clouds, observed by Japanese explorers as well as by Capen $\left({ }^{3}\right)$, may be also attributed to volcanic outbursts. There are some observations, carried out by Dollfus $\left({ }^{10}\right)$, which revealed the existence of relatively small, white, persistent clouds over certain Martian regions which can be interpreted as white vapour-clouds emitted by Martian volcanoes.

The author of the present study has investigated the distribution of these phenomena over the Martian surface and found that the distribution is not random. The events occurred - in the overwhelming majority of the cases - on areas which are lying along the transitional region between dark and bright territories. It is important to note that many of the lunar transient events (probably postvolcanic phenomena) have a similar position on the lunar surface, that is they can be found mostly at the border of Iunar continents or basins respectively. On the other hand the most important volcanic zones of the Earth are also to be found along the edges of the Pacific basin.

(*) Paper presented at Montreal on the Meeting "New Approaches to Planetological Problems", August, 1972, on the occasion of 1st Plenary Session of the International Association of Planetology at the IGC.

(**) F.R.A.S., President of International Lunar Society, Vice-President of International Association of Planetology. II. Arpád fejedelem utja 40-41, IV/3, Budapest, Hungary. 
Russuxwo. - Sin dalla fine del secolo scorso diversi ricercatori riferirono di fenomeni di luci intermittenti da loro osservate su Marte. Secondo il parere di Heuseler $\left({ }^{11,12,13}\right)$, Katterfeld $\left({ }^{14}\right)$, Saheki $\left({ }^{15}\right)$, Sato $\left({ }^{16}\right)$ ed altri autori, tali segni luminosi potevano significare l'esistenza sul pianeta di vulcani attivi. Anche le nuhi grige, osservate da ricercatori giapponesi, oltre che da Capen $\left({ }^{3}\right)$, possono essere attribuite ad eruzioni vulcaniche. Altre osservazioni, fatte da Dollfus $\left({ }^{10}\right)$, rivelavano lesistenza di nubi bianche, persistenti, relativamente piccole, sopra certe zone marziane che si possono interpretare quali emanazioni bianche di vapore, provenienti da vulcani marziani.

L'autore di questo studio ha esaminato la distribuzione di tali fenomeni sopra la superficie di Marte ed ha trovato che essa non è avvenuta a casaccio. I fatti si sono verificati, nella stragrande maggioranza dei casi, in zone situate lungo la fascia di transizione tra i territori scuri e quelli chiari. In proposito è importante notare che molti eventi lunari transitori, probabilmente fenomeni post-vulcanici, occupano una posizione analoga sulla superficie della Luna, cioè si trovano soprattutto ai confini dei continenti o dei bacini lunari. Daltra parte, anche le zone vulcaniche più inportanti della Terra si trovano lungo i bordi del bacino del Pacifico.

American spacecraft Mariner-9 as well as a Soviet one from the series of recent Mars-rockets have revealed at least two small areas on the planet's surface where the local temperature of the ground is higher with some 10 degrees than in their proximity. It seems to be logical to suppose that these relatively "hot" regions represent areas where active solfatara-fields exist.

On the basis of the photos, made by the Mariners one can suppose that in ancient times as well as in the recent "geological" past the volcanic activity had an important role in the development of the Martian crust and surface. Some important and interesting features were discovered among them ringmounts, which are very similar to the terrestrial calderas of collapse-origin. The terrain inside one of these Martian calderas has an appearance of a typical lava-flow. It is important to note that some flares and grey as well as small persistent white clouds appeared on areas where ringmounts and caldera-like formations can be found. Furthermore small volcanic chains parallel with a tectonic chasm, little holes with a diameter of $1 \mathrm{~km}$ or even smaller (probably volcanic vents from which gases escaped), meandering valleys (by all probability remnants of underground lava-tubes), and last but not least cracks in the Martian crust, similar in appearance to the linear eruptions of Iceland were recognized. 


\section{HISTORICAL BACKGROUND}

According to Davidov $\left(^{6}\right)$ the first astronomer who observed a flare on Mars was J. M. Offord in 1896. Further earlier observations were made by P. Lowell (in 1900 and 1903); G. Fournier and V. Fournier (1911); N. P. Barabashev (1924), and S. Mayeda (1937). In more recent times two Russian experts also made similar observations, namely V. P. Bedenko and A. P. Kutireva (1956).

The first theory concerning the possibility of volcanic eruptions on Mars was developed by E. M. Antoniadi. Observing the Deucalionis Region of Mars in 1909 and in 1911, he perceived grey clonds above it and on this basis he supposed that there are active voleanoes on the planet.

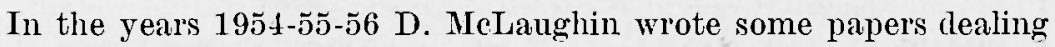
with the similar problem and supposed that the Martian volcanoes are to be found first of all in the bay-like formations of the surface of Mars. His ideas generally were rejected by other astronomers.

\section{Flares}

The Martian flares are sudden and short-lived light-phenomena usually in white or yellowish-white colour. Their life-time generally is only some minutes. Their brightness often is rather strong; sometimes they are as bright as the white polar caps of the Mars, sometimes they are even brighter.

As regards the interpretation of these phenomena, Saheki (15) wrote as follows:

"I would like to explain these phenomena as the sudden development of white clouds of moisture brought about by rapid upward currents in the atmosphere due to very complex local meteorological phenomena over these limited areas, or else to the rapid development of clouds of moisture produced by the great force of active volcanoes which erupt intermittently".

We collected all the data available at the present time and compiled a list (Table I), probably the most complete one ever published in this respect. The sources of data about Martian flares were as follows: Capen ( $\left.{ }^{3}\right)$, Heuseler (11), Katterfeld (14), Saheki (15) and Sato (16), 
respectively. An event, observed on January 6,1961 , and reported by E. E. Both in "The Strolling Astronomer", Vol. 15, No. 3-4, was also included into the list, although the true nature of the observed phenomenon is not clear enough.

$\mathrm{T} a \mathrm{ble} \mathrm{l}$

\begin{tabular}{|c|c|c|c|c|}
\hline l)ate & Observer and & telescope & Location on Mars & $\begin{array}{l}\text { Re- } \\
\text { mark }\end{array}$ \\
\hline 1937.06 .07 & S. Mayeda, & $8^{\prime \prime}$ refl.* & $\begin{array}{l}\text { Close to Sithonius Ia } \\
\text { cus, }-55^{0}, 240^{0}\end{array}$ & 1 \\
\hline 1951.12 .08 & T. Saheki, & $8 "$ refl. & $\begin{array}{l}\text { Western portion of e- } \\
\text { quatorial 'Tithonius } \\
\text { Lacus }\end{array}$ & 2 \\
\hline 1954.07 .01 & T. Saheki, & $8^{\prime \prime}$ refl. & $\begin{array}{l}\text { Edom Promontorium } \\
\text { (at the equator) }\end{array}$ & 3 \\
\hline 1954.07 .23 & T. Saheki, & $8^{\prime \prime}$ refl. & $\begin{array}{c}\text { Mare Acidalium, SW } \\
\text { part, }+35^{0}, 42^{0}\end{array}$ & 4 \\
\hline 1954.07 .24 & C. Mcclelland & $1,13^{\prime \prime}$ refr. ${ }^{* *}$ & Edom Promontorium & 5 \\
\hline 1958.11 .05 & S. Murayama & 8 " refr. & $\begin{array}{l}\text { South of Tanais Pla- } \\
\text { teau, SW edge of } \\
\text { Aphrodite Mare (A. } \\
\text { cidalia), }+\mathbf{3 5}^{0}, 42^{\circ}\end{array}$ & 6 \\
\hline 1958.11 .06 & S. Tanabe, & $3,5^{\prime \prime}$ refl. & $\begin{array}{l}\text { Tithonius Iacus, South- } \\
\text { ern edge }\end{array}$ & 7 \\
\hline 1958.11 .10 & S. Fukui, & $10^{\prime \prime}$ refl. & Solis Lacus, NE part & 8 \\
\hline 1958.11 .21 & T. Saheki, & $8 "$ refl. & $\begin{array}{l}\text { Northern edge of Hel- } \\
\text { las and Edom Pro- } \\
\text { montorium }\end{array}$ & 9 \\
\hline 1958.11 .21 & I. Tasaka, & $13^{\prime \prime}$ refl. & $\begin{array}{l}\text { Northern edge of Hel- } \\
\text { las and Edlom Pro- } \\
\text { montorium }\end{array}$ & 10 \\
\hline 1960.10 .08 & T. Saheki, & 8" refl. & 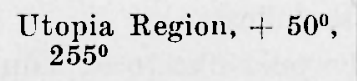 & 11 \\
\hline 1961.01 .06 & N. Schneller & $?$ & Northern polar cap & 12 \\
\hline 1967.03 .20 & S. Miyamoto & $12^{\prime \prime}$ refr. & $\begin{array}{l}\text { Arcadia and Neith Re- } \\
\text { gions }\end{array}$ & 13 \\
\hline 1967.04 .21 & S. Miyamoto & $12^{\prime \prime}$ refr. & Hellas & 14 \\
\hline 1967.05 .05 & S. Miyamoto & $12^{\prime \prime}$ refr. & Nix Olympica & 15 \\
\hline
\end{tabular}

The remarks are to be found in Table II. 
Table I I

\begin{tabular}{|c|c|}
\hline Serial number & Remark \\
\hline 1 & $\begin{array}{l}\text { Considerably brighter than the polar cap and the white } \\
\text { clouds. Flickering like a star, and after } 5 \text { minutes it } \\
\text { was hidden from view (possibly due to rotation of } \\
\text { the planet) }\end{array}$ \\
\hline 2 & $\begin{array}{l}\text { Brighter than the north polar cap. Flickering light and } \\
\text { stellar brightness of the 6th magnitude for } 5 \text { minutes. } \\
\text { It then began to be extinguished and changed into a } \\
\text { grayish cloud having a diameter of more than } 300 \mathrm{~km} \text {. } \\
\text { The entire phenomenon lasted about } 40 \text { minutes }\end{array}$ \\
\hline 3 & $\begin{array}{l}\text { In } 10 \text { seconds the colour changed from a whitish-yellow } \\
\text { to a bright, pure white, and then changed to yellow- } \\
\text { ish-white. Duration of the flare was } 5 \text { seconds }\end{array}$ \\
\hline 4 & $\begin{array}{l}\text { From the 23rd, July to the 3rd, August, 1954, more } \\
\text { small, very bright clouds were observed on the area } \\
\text { where according to MIurayama (see no } 6 \text { ) - a } \\
\text { small but bright spot occurred }\end{array}$ \\
\hline 5 & $\begin{array}{l}\text { Tlare was visible for about } 58 \text { seconds. In the opinion } \\
\text { of the observer, it was caused by a volcanic eruption }\end{array}$ \\
\hline 6 & $\begin{array}{l}\text { Small but very bright spot, white in colour. I asted } \\
\text { about } 5 \text { minutes }\end{array}$ \\
\hline 7 & Brightness as same as for the polar cap for 4 minutes \\
\hline 8 & $\begin{array}{l}\text { Brightness same as for the polar cap for } 5 \text { minutes. Jia- } \\
\text { meter of the spot is estimated to be about } 250 \mathrm{~km}\end{array}$ \\
\hline 9 & Two bright spots \\
\hline 10 & $\begin{array}{l}\text { The same spots as above, (see no 9). Yellowish-white } \\
\text { clouds over the Northern part of Hellas. Both flares } \\
\text { lasted about } 5 \text { minutes, together with phases of increase } \\
\text { and decrease in brightmess: } 15 \text { minutes. After several } \\
\text { minutes, the flares reappeared. The observation of } \\
\text { Saheki and Tasaka had taken place on the same night, } \\
\text { however not in the same hour. They worked quite } \\
\text { independently from each other. When Tasaka began } \\
\text { his own observation, Saleki already finished his one. } \\
\text { The disappearance of the flares lasted only about } 10 \\
\text { minutes. }\end{array}$ \\
\hline 11 & $\begin{array}{l}\text { Small spots, similar in brightness to that of the polar } \\
\text { cap. When the first spot disappeared there had been a } \\
\text { pause lasted about } 8 \text { minutes, after which a new one } \\
\text { appeared just on the some position }\end{array}$ \\
\hline 12 & This is a very doubtful observation \\
\hline 13 & 'lwo short-lived white spots \\
\hline 14 & Short duration \\
\hline 15 & Three white spots of short duration \\
\hline
\end{tabular}




\section{Onjnetroxis}

Davidov $\left(^{6}\right)$ has pointed out that many of the flare-observations can be interpreted by other way as well. According to him the bright patches "could have been a directed reflection of solar rays from a cloud of ice crystals in the Martian atmosphere, giving a parhelic halo. Alternatively, the directed reflection could have been in principle produced by reflection from a nearly vertical surface situated upon the planet itself. The short duration... would be explained by the planet's rotation".

De Vaucouleurs $\left({ }^{7.8}\right)$ is on the opinion that the observations, made more than ten years ago "were not real; at the time reported for the observations the side of Mars turned toward the Earth was not that which was depicted by the observer. Furthermore, the apparent diameter of Mars was much too small and the telescope aperture insufficient to show the amount of detail represented by the sketches".

Taking these objections - especially that of De Vaucouleurs into consideration, we must proceed very cautionsly in the judgement of the nature of these phenomena. For instance events numbered as 7 and 12 are doubtful since in the first case the aperture of the telescope was very small and in the second case the data of the instrument is not given. However there are some factors which are in favour of the reality at least of a part of the observations. Thus: events, numbered as 2 and 7 , furthermore as 4 and 6 were observed by two persons who were working independently from each other. According to them the phenomena occurred almost on the same place of the Martian surface. These events had taken place in different years. Fvents 9 and 10 were observed also by two independent explorers during the same night. The position of the respective spots was the same. On the other hand there are factors which agree with the volcanic hypothesis. Namely events signed by number 15 (three spots) occurred in the Nix Olympica Region and Nix Olympica by all probability is a gigantic caldera of collapse origin. According to our knowledge the volcanic activity can start again inside the caldera ajter the collapse-process (e.g. Krakatau, Santorin, etc.). Furthermore, the flare, observed by Saheki on the 8th, December, 1951, had been followed immerliately by the development of a large grey cloud over the same point. Accepting the theory, explained by Davidov $\left({ }^{6}\right)$, this phenomenon would be quite incomprehensible. But accepting the volcanic theory, the cause of this 


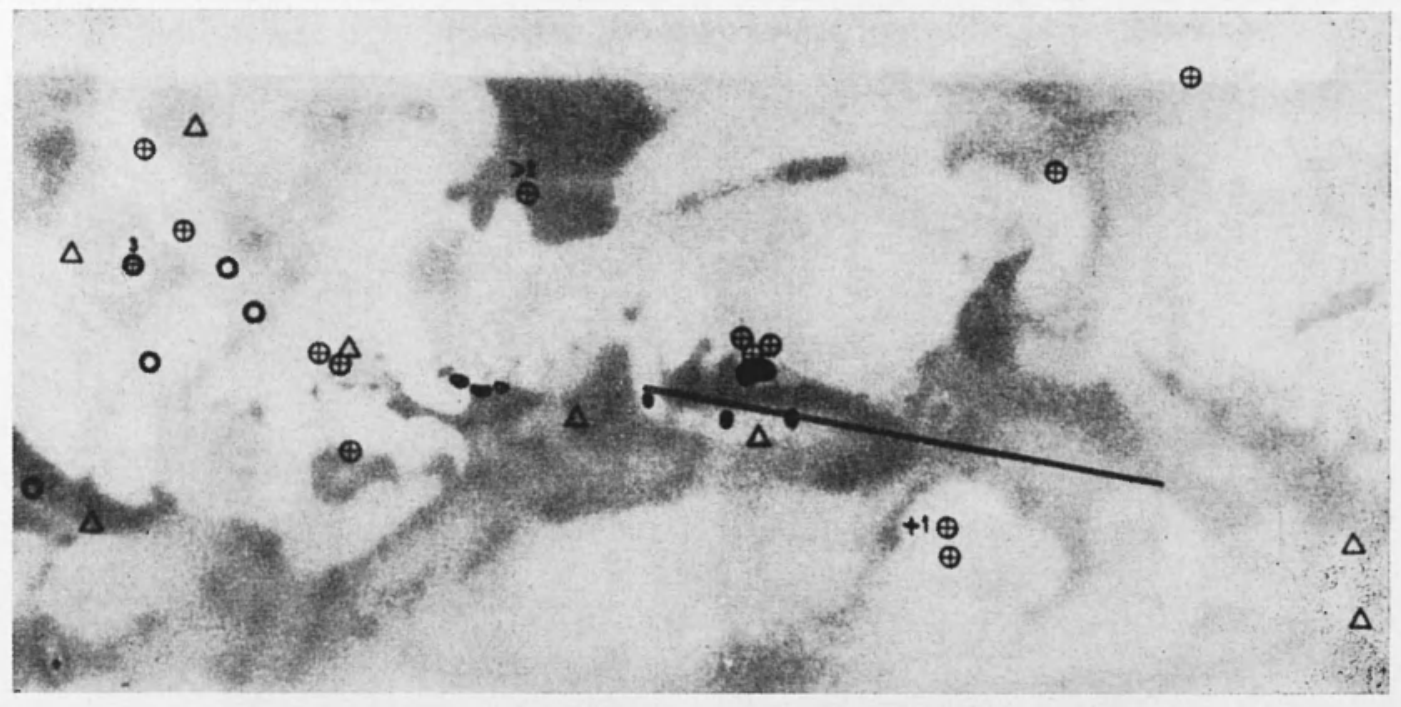

Fig. 1. - Distributions of flares, individual grey clouds, a grey streak, small persistent white clouds and the five known calderas on Mars. I.egend:

$\oplus$ flares;

$\Delta \quad$ grey clouds;

- the gray streak;

$\frown \quad$ small persistent white clouds;

$\bigcirc$ calderas;

$\therefore-1$ an additional flare; the exact location of which is not known but it occurred inside Hellas;

$>2$ the number of flares on the respective spot was greater than two but the exact number is not known;

3 there (at the Nix Olympica Region) the observed number of white sports was three.

The map is due to De Vaucouleurs; the data in figure were compiled and drawn by the author using the data of the scientists mentioned in the text. 
phenomenon is clear: one can assume that the flare was the consequence of a white vapour-cloul emitter by a Martian voleano while the grey cloud after it might have been a voleanic ash-one.

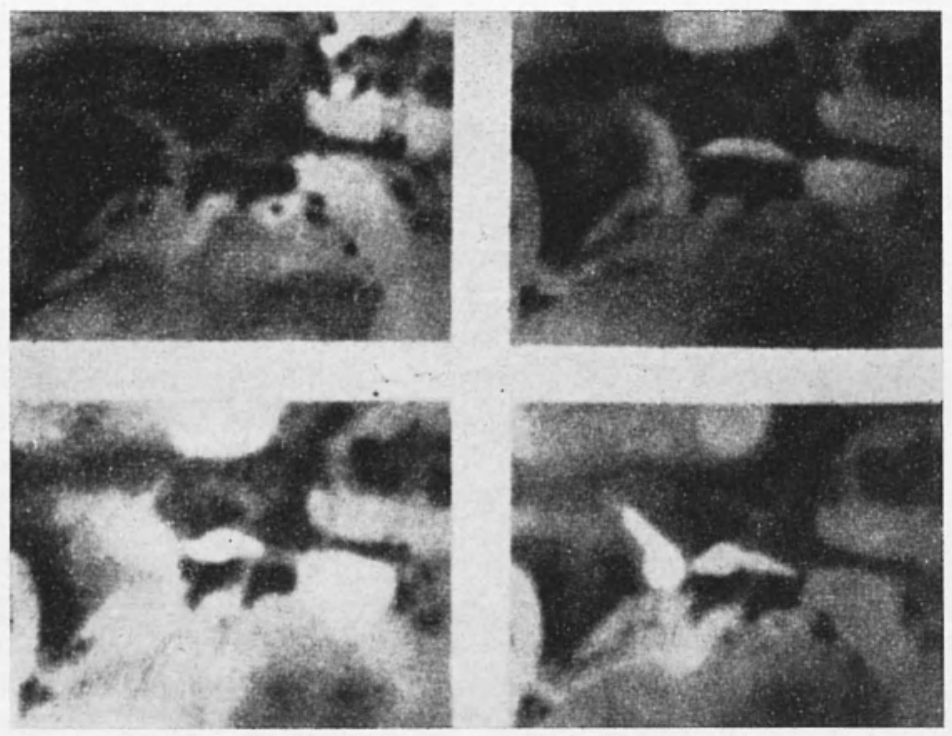

Fig. 2. - Sinill persistent clouds over Protei, Pyrrhae and Ophir Regions. Above: September 2 and 30, 1956. Below: October 4 and 8, 1956. After Dollfus.

Finally, as a further argument in favour of the voleanic nature of some of Martian phenomena, we can refer to the other greyish clouds as well as to the small persistent white clouls. These features will be briefly discussed later.

\section{DISTRIBUTION OF FLARES}

Jet us now accept as a working-hypothesis that the flares really can be attributed to volcanic activity. In this case it seems to be interesting to investigate the distribution of these phenomena on the surface of the Murs (supposing that their position was given correctly by 
the observers) and to take a comparison with the distribution of lunar transient phenomena (which can be regarded as postvolcanic events) as well as that of the terrestrial volcanic areas.

Most of the events occurred in areas which are lying along the transitional region between dark and bright territories of the Martian landscape. A rather similar distribution can be experienced in the
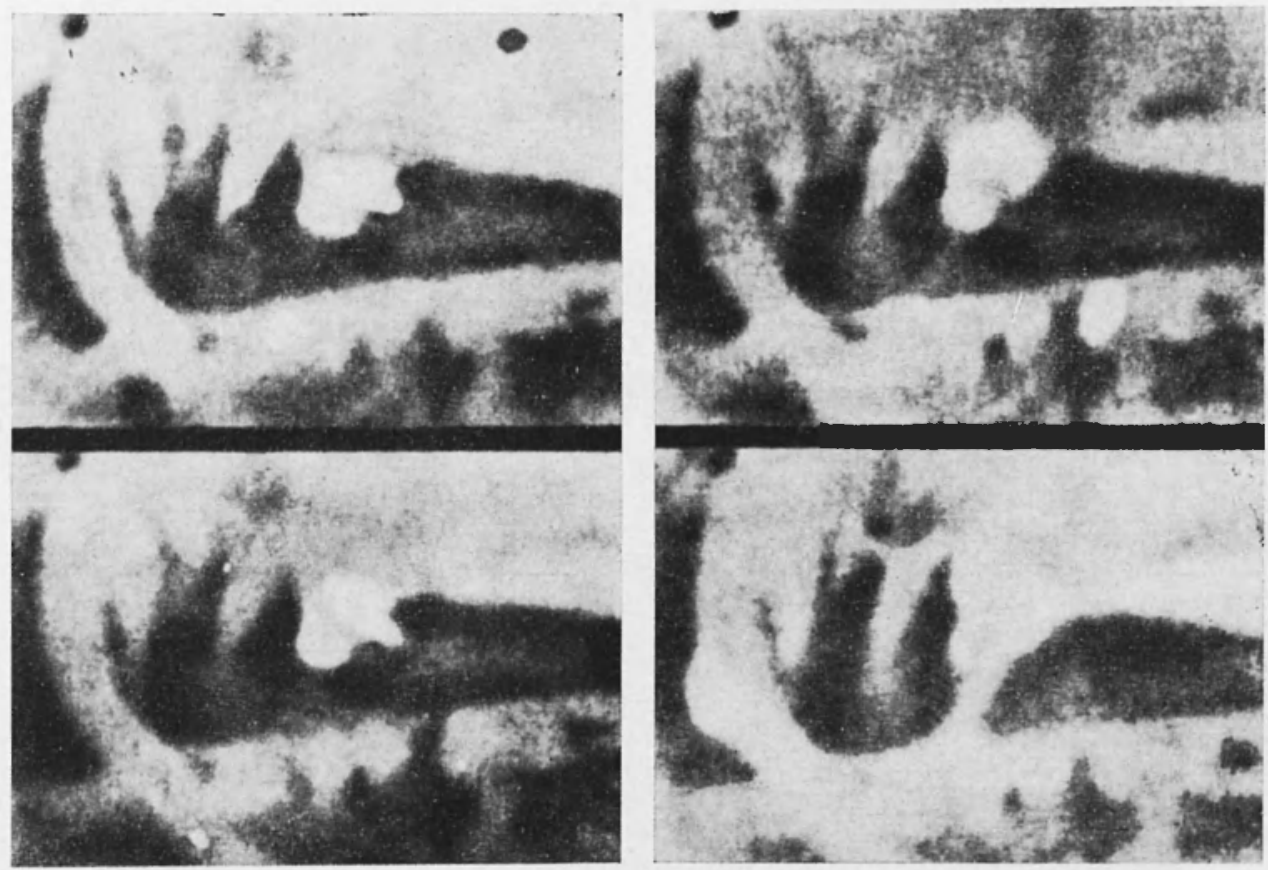

Fig. 3. - Small persistent clouds over Edom Region. On tho left side: September 7 and October 8, 1956. On the right side: October 12 and 13 , 1956. First drawing by J. Focas; others by Dollfus.

case of small persistent white clouds and of individual grey clouds as well. It is interesting to note that many of the flares and clouds occurred in bay-like formations as it was supposed by McLaughlin. As we know, McLaughlin expressed his opinion purely on theoretical base.

In some cases flares had taken place in the area of Hellas, which can also be regarded as an exceptionally large ring-like features (caldera of collapse origin?). 
The lunar transient phenomena - in their overwhelming majority - are situated at the edges of the large basins of the Moon $(2,5)$. On the other hand the most important active volcanoes of the Fasth can also be found along the edges of the basins. It seems that this distribution is a natural law valid for the terrestrial-type planetary bodies. The zones of weakness, which are favourable for volcanic

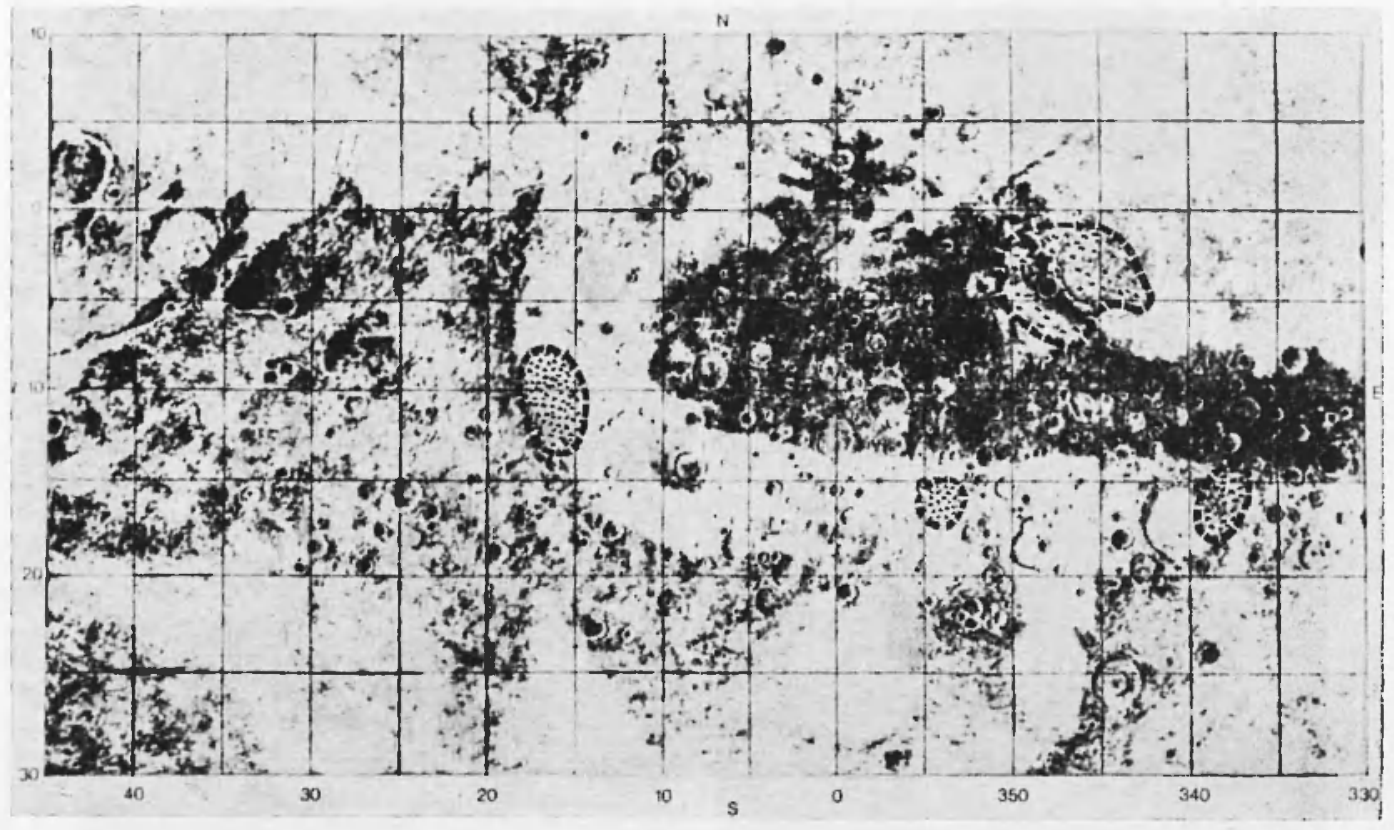

Fig. 4. - The small white clouds of Edom, indicated on a map, made by the photos of Mariners 6 and 7 .

activity developed first of all on areas, lying between basins and continental-like regions.

\section{SMaLl PERSistent White ClOUDS}

J. Focas and A. Dollfus observed small white clouds located above Edom Region (September 7, October 8, 12 and 13, 1956), furthermore above Protei and Pyrrhae Regions and Ophir (September 2, 30 - October 
$4,8,1956)^{10}$. These bright, white clouds of small apparent size were isolated features in the Martian atmosphere and generally remained above the same locality. Some of them were around $100 \mathrm{~km}$ in diameter $\left({ }^{9}\right)$. The one above Edom appeared on each day with a new shape. Smallsized, bright clouds, remained fixed in position were seen

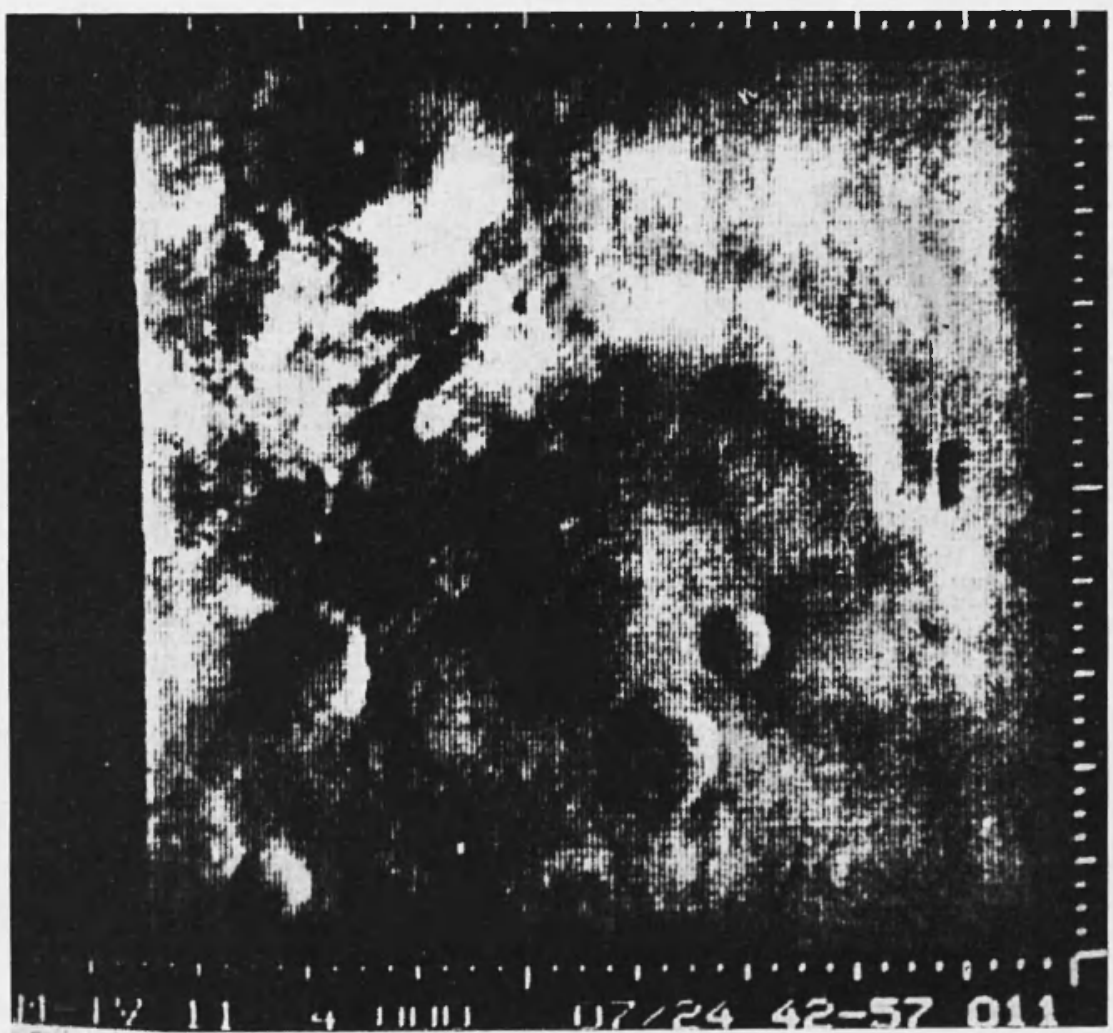

Fig. 5. - Gigantic caldera-like formation on the Mars (frame 11. of the series of Mariner-4 photos).

at Nix Olympica Region as well, which is - as it was mentioned above - a caldera of collapse origin.

It may be that the respective small persistent clouds are of volcanic origin, namely thay are white water-vapour clouds without volcanic ash and dust. The author had drawn them onto a detailed map 
of the Sinus Meridani - Edom - Sinus Sabaeus - Deucalionis Regions. The respective map was made on the basis of Mariner-photos (Mariners 6 and 5 ), and the Martian ringmounts were indicated on it. We experienced that two of the four clouds had been in direct connec-

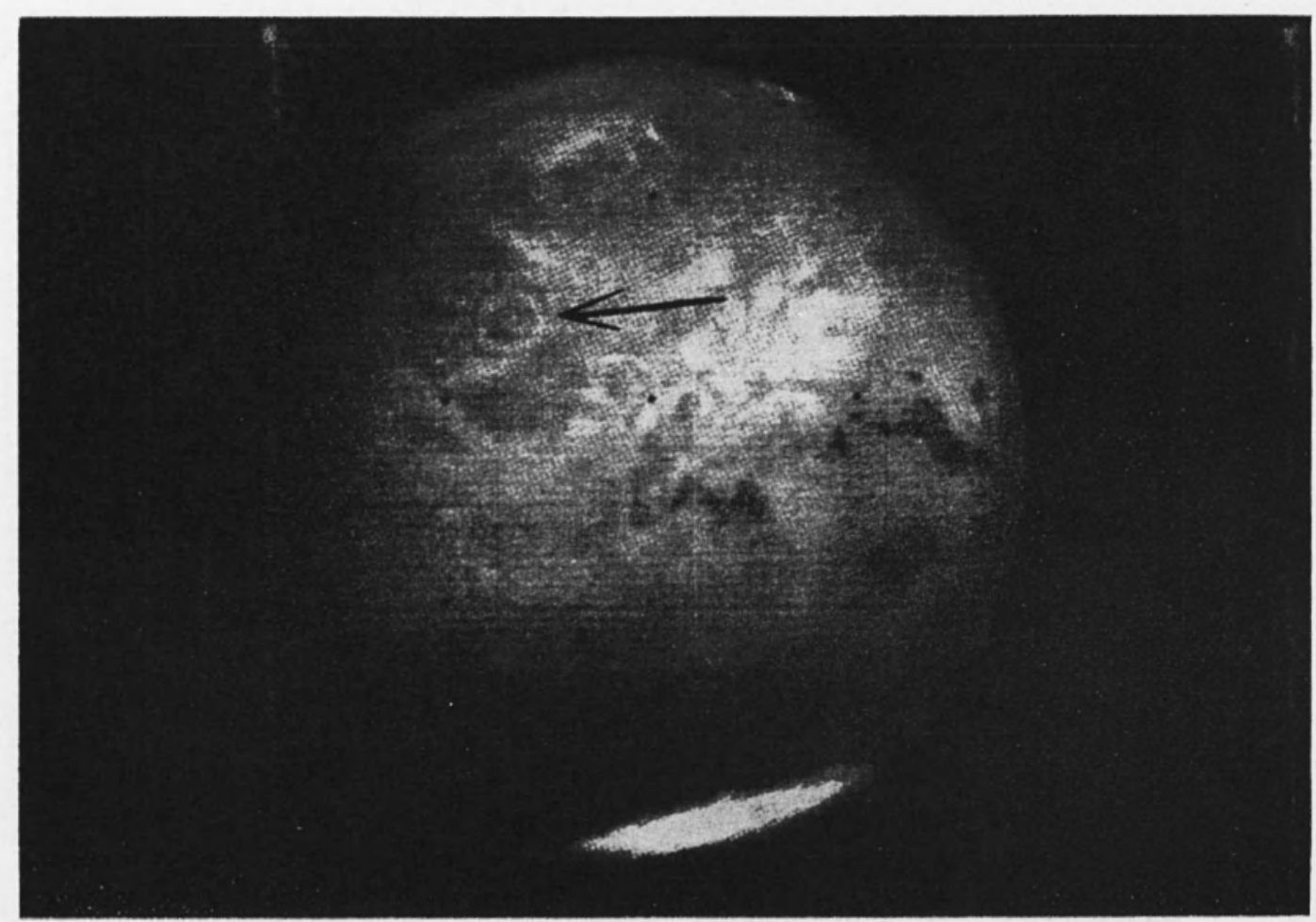

Fig. 6. - The Nix Olympica Region is marked by an arrow on this Mariner photo.

tion with ringmounts in that meaning, that they appeared just over the walls of these rings. The third cloud was located between three small craters. In the case of the fourth cloud there was no any connection with ringmount-formations.

Burgess ( ${ }^{1}$ ) has reported, that 'by targeting Mariner - 9's cameras at known areas of white clouds, project scientists discovered four major calderas, with which they seem to be associated. They could arise 


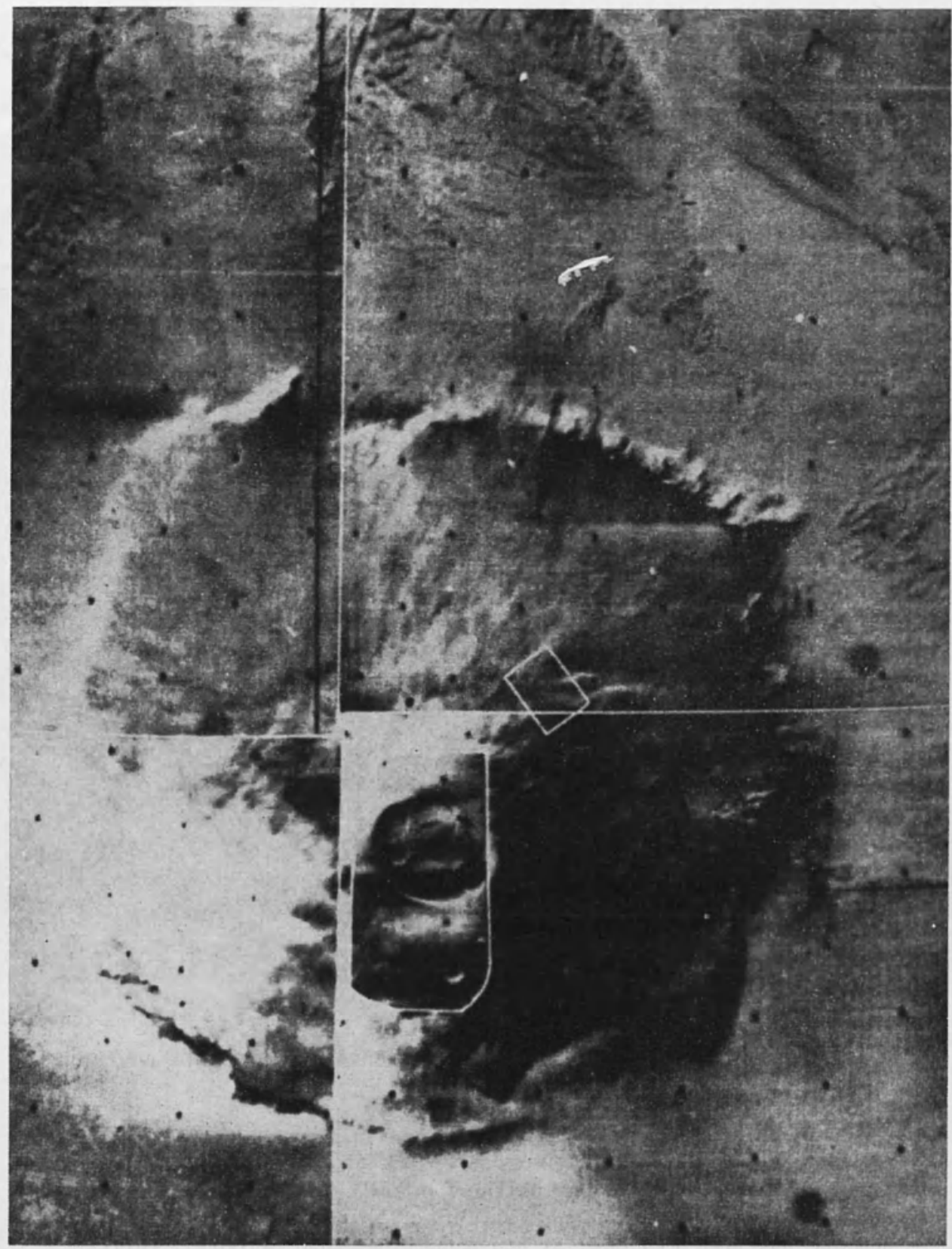

Fig. 7. - A detailed photo-mosaic of Nix Olympica caldera (Mariner-9 photo). The area inside the oblique frame can be seen in an enlarged form on Fig. 8 (after Scientific American). 
from afternoon condensation of voleanic gases emitted during the day. Alternatively the clouds could be general atmospheric condensations analogous to those over Earth's high mountains. In the former inter-

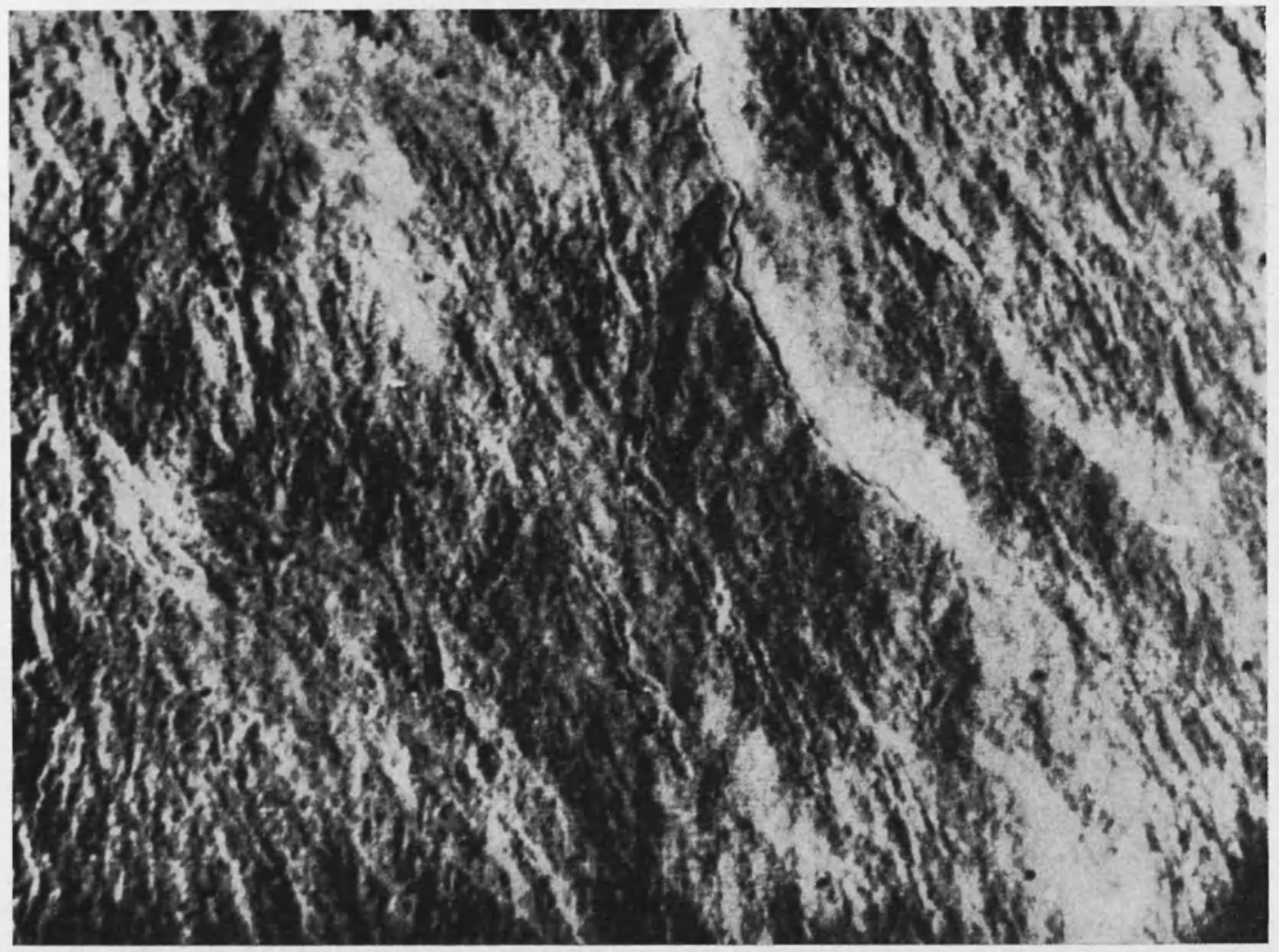

Fig. 8. - $\Lambda$ part of Nix Olympica's interior: we can see a typical lava-flow (after scientific American).

pretation the clouds would be positive evidence of continuing volcanic activity on the planet" *.

(*) Capen (') had the kindness as to call the author's attention to the followings: "Certain light areas do show brightly each Martian morning as if the white substance is deposited during the cold Martian night. This activity has been explained as atmospheric seasonal activity. However. it is quite possible that some of these white areas are due to volcanic outgassing which is frozen out on the surface as frost each night. Such areas as Ophir, Tharsis, Nix Olympica, Nix Lux, etc., are suspects. 


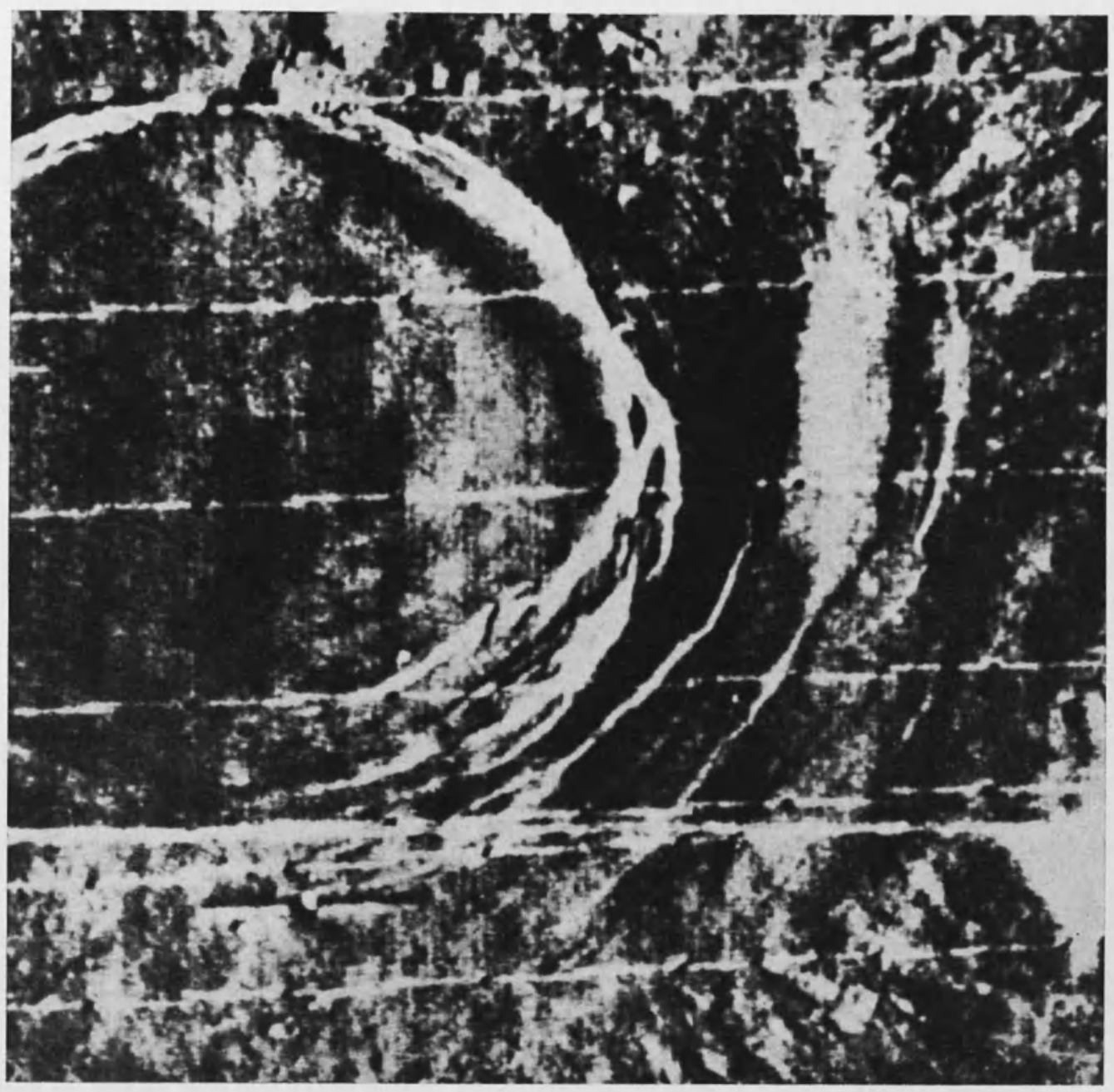

Fig. 9. - Terrace-like steps in the Norlus Gordii caldera of Mars. Photo made by Mariner-9. Diameter of caldera is about $110 \mathrm{~km}$.

Concerning this point, we may mention that also according to Burgess (1): "Mars' several major volcanic areas must have been active in geologically recent times because their lava flows are almost free of impact craters. Nix Olympica and the three dark spots associated with Nodus Gordii, Biblis Pons, and Gigas, together with Elysium form major centres of volcanic activity on the planet". 


\section{GREY CLOLDS AND GREY STRIPEN}

There are some indications concerning the existence of grey clouds and stripes of such grey formations in the atmosphere of the Mars. These clouds ditfer very much from the wellknown other clouds and therefore a new interpretation seems to be necessary for their origin.

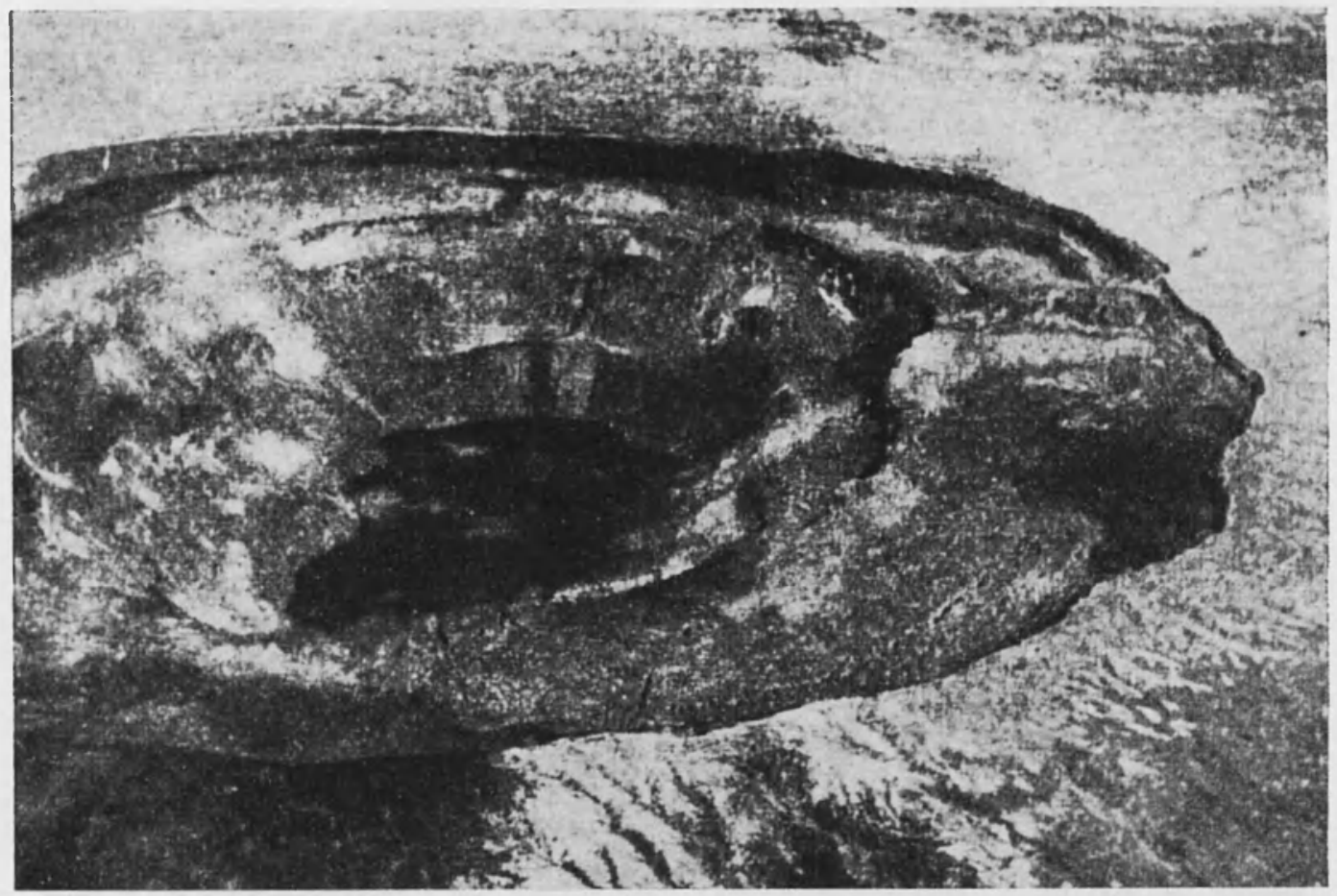

Fir. 10. - In order to comparing with Fig. 9: a caldera at Hawaii (after Science et Vie).

As it was mentioned in the introduction of the present paper, the first explorer, who had an opportunity to observe grey clouds on the Mars, was Antoniadi. On the 15th, January, 1950, T. Saheki perceived a gigantic grey cloud over Eridania and Electris. The diameter of the formation was estimated to be about $750 \mathrm{~km}$. Further observations were marle by Ebizawa on the 29th, March, 1960 (southeastern part of Nare Sirenum), by Saheki on the 8th, December, 1951 (as it was mentioned earlier, after a flare over the Western portion of Tithonius Lacus; 
the diameter of the cloud was abont $300 \mathrm{~km}$ and Saheki was able to observe it during about 40 minutes); by S. Fbizawa again between March and May of 1962 (over Eridania and Mare Cimmerium; more exactly speaking: on the common borler of these two areas, Eridania is a bright region while Mare ('immerium is a dark one) and last but not

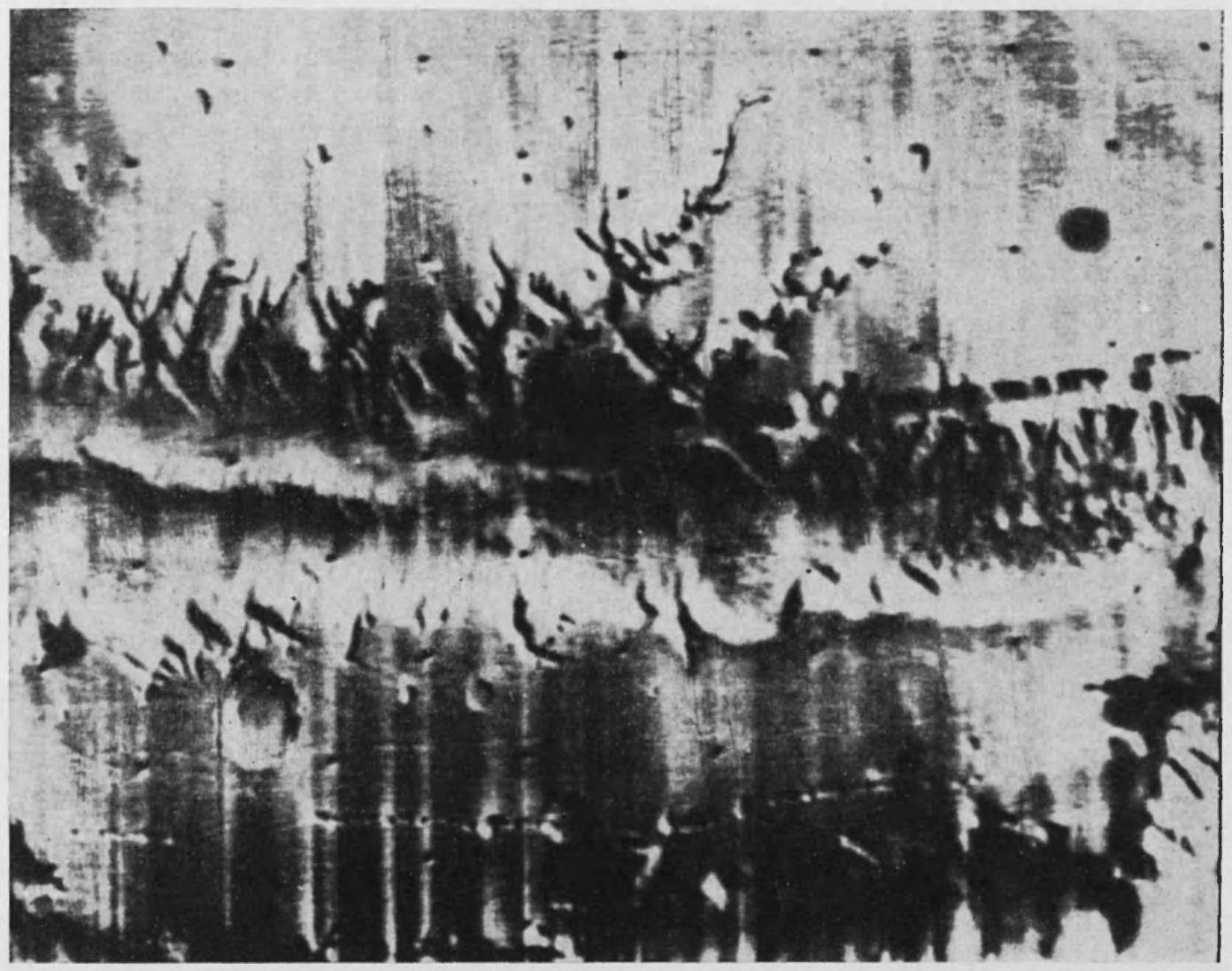

Fig. 11. - Chasm probably of tectonic origin and a chain of small craters roughly parallel with it. Photo was made by Mariner-9.

least by Capen on the occasion of the opposition of Mars in 1962-63. Between 9 and 12, January, 1965, Capen observed dark stripes, the form and position of which changed considerably. Similar long and 
narrow dark streaks had not been observed previously. Miyamoto (*) las observed greyish, strange haze over the Amazonis and Arcadia Regions, not too far from Nix Olympica, simultaneously with the appearance of three white spots at the Nix Olympica region (5th, May, 1967).

Katterfeld (1+) has mentioned that the exact position of the mighthy cloud, observed by Saheki on the 15th, January, 1950, was as follows: $-58^{\circ}$ and $202^{\circ}$ and the cloud was located at an altitude of $100-200 \mathrm{~km}$ above the surface of the planet. This cloud is not indicated on our map of quasi-volcanic phenomena of the Mars, since the Katterfeld's respective study reached the present author too late when the matp was completed and finished alrearly.

Accepting that these grey clouds may be of volcanic origin and they are clonds of volcanic dust and ash, we can state that the force of some of the Martian eruption must be very consiclerable. The outburst, the signs of which were observed by Saheki on the 15th, January, 1950, must have had a magnitude similar to that of Krakatau (1883) of Bezymianny (1956) when the cloud reached a height of $80 \mathrm{~km}$ (Krakatau) and $36 \mathrm{~km}$ (Bezymianny) respectively.

As regards the grey stripes, observed and mentioned by Capen $\left({ }^{3}\right)$, we can suppose that these might have been not the signs of a simple central eruption only, but of a linear eruption probably similar to the Laki fissure eruption in 1783 at Iceland, when gigantic mass of basaltic magma reached the surface of the Earth.

VOLCANIC FORMS ON MARS

Finally let us summarise the evidences concerning the existence of true volcanic lanclscape-forms on Mars.

Spacecraft Mariner-9 has revealed the existence of four calderalike formations on Mars. These are as follows [coordinates after Henseler (13)]:

$\begin{array}{ll}\text { Norlus Gordii } & -2 \circ, 135^{\circ} \\ \text { Lacus Ascraeus } & +20^{\circ}, 117^{\circ} \\ \text { Nix Olympica } & +25^{\circ}, 130^{\circ} \\ \text { Pavonis Lacus } & +10^{\circ}, 110^{\circ} .\end{array}$

$\left(^{*}\right)$ The data concerning the observations made by Professor S. Miya. moto were given in Heuseler's paper, 1969. 


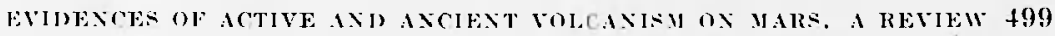

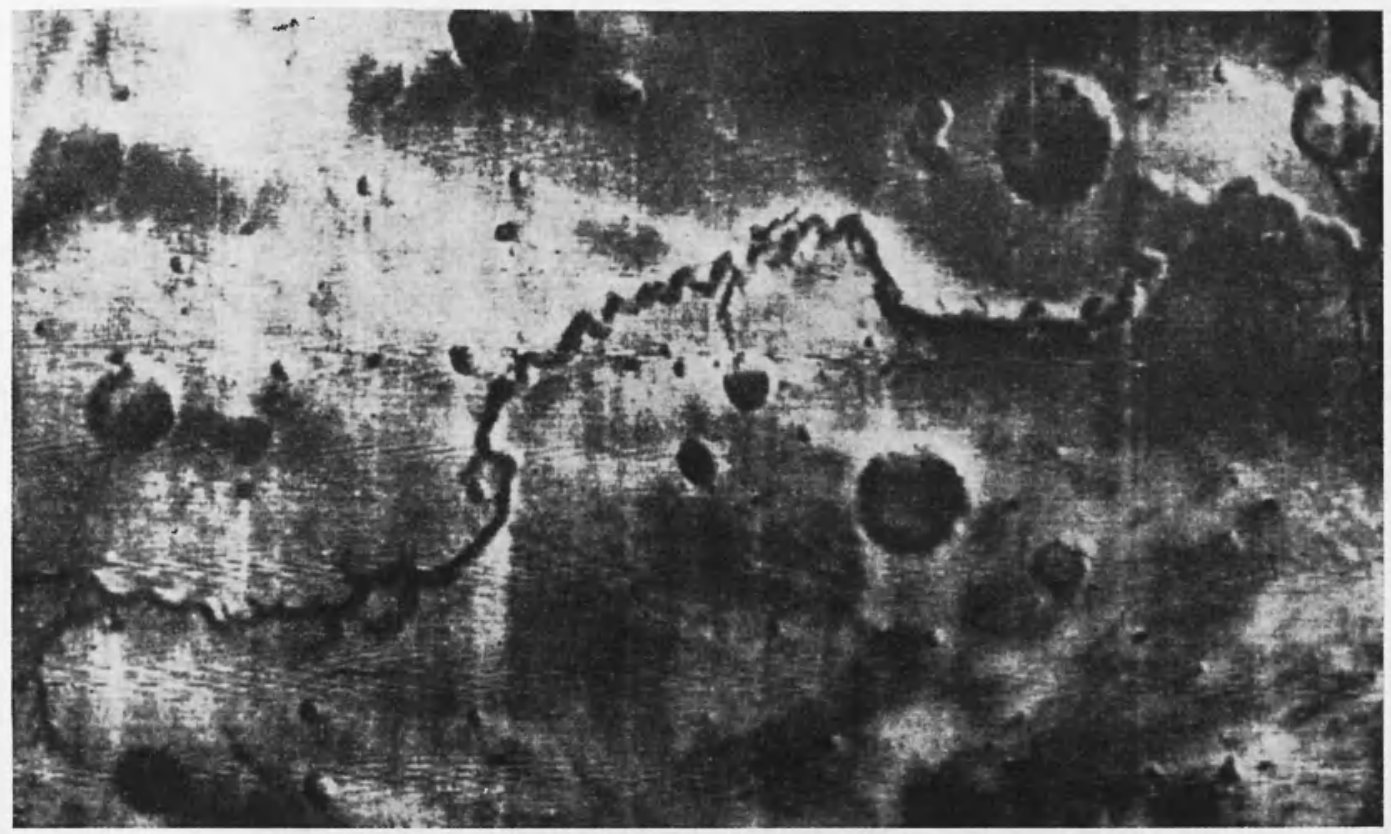

Fig. 12. - Meandering valley on the Mars - supposedly remnant of an underground lava-flow (after Sky and Telescope). Mariner-9 photo.

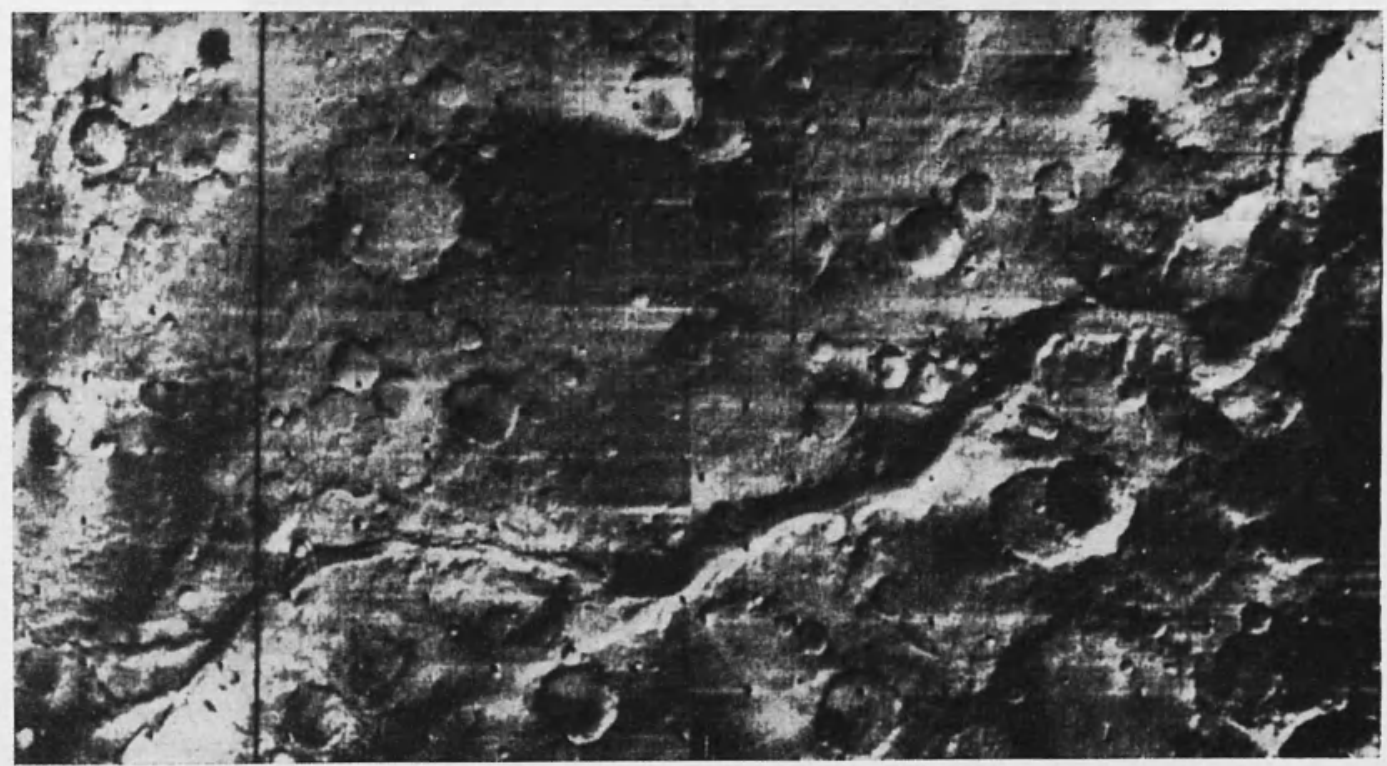

Fig. 13. - An other meandering valley (after Sky and Telescope). Photo made by Mariner-9. 


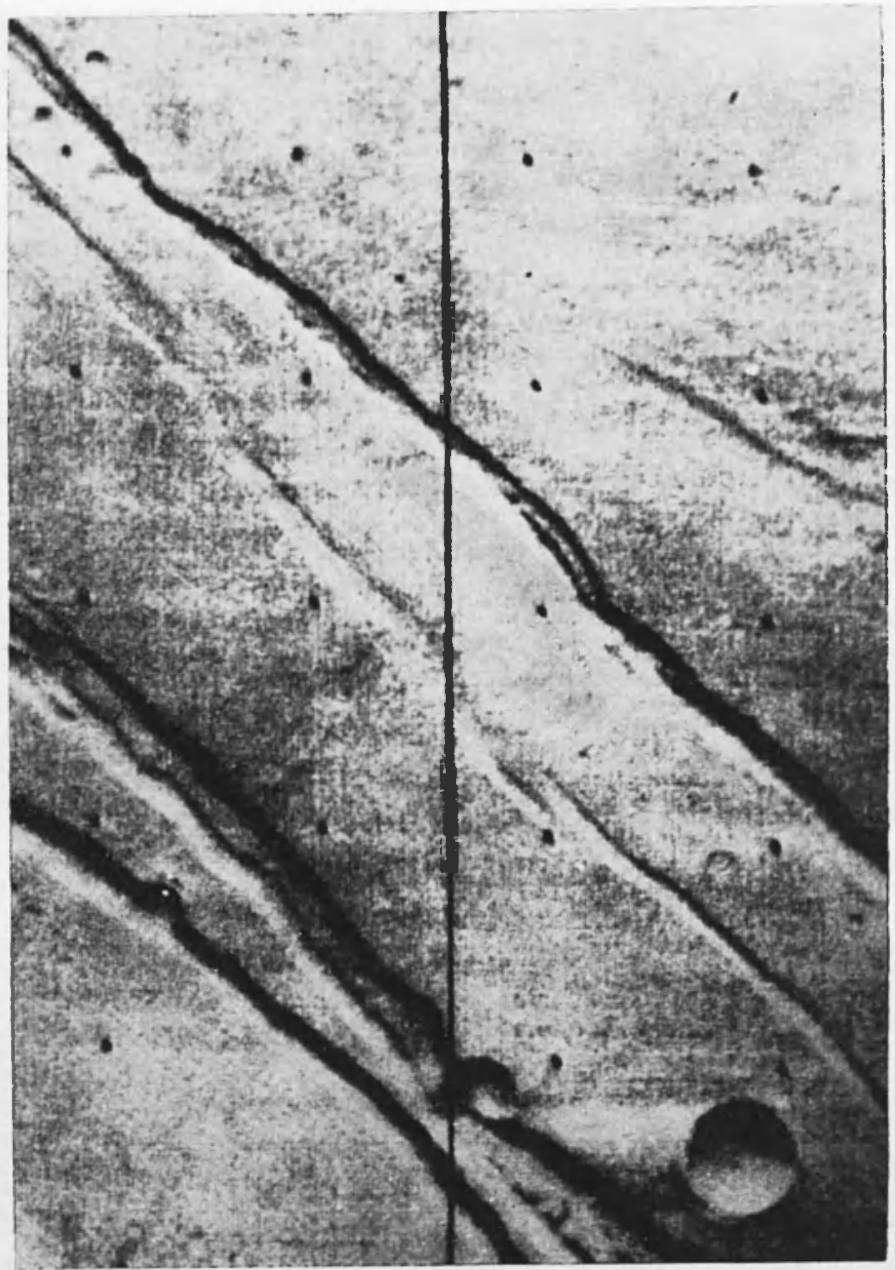

l'ig. 14. - Ronghly parallel fissures on the Mars (after Scien. lifie American). Photo made by Mariner-9.

Note: according to De Vaucouleurs $\left(^{8}\right)$ the coordinates are the followings:

$\begin{array}{lr}\text { Nodus Cordii } & -50^{\circ}, 130^{\circ} \\ \text { Isacus Ascraeus } & +18^{\circ}, 100^{\circ} \\ \text { Nix Olympica } & +20^{\circ}, 138^{\circ} \\ \text { Pavonis Iareus } & 0^{\circ}, 114^{\circ}\end{array}$




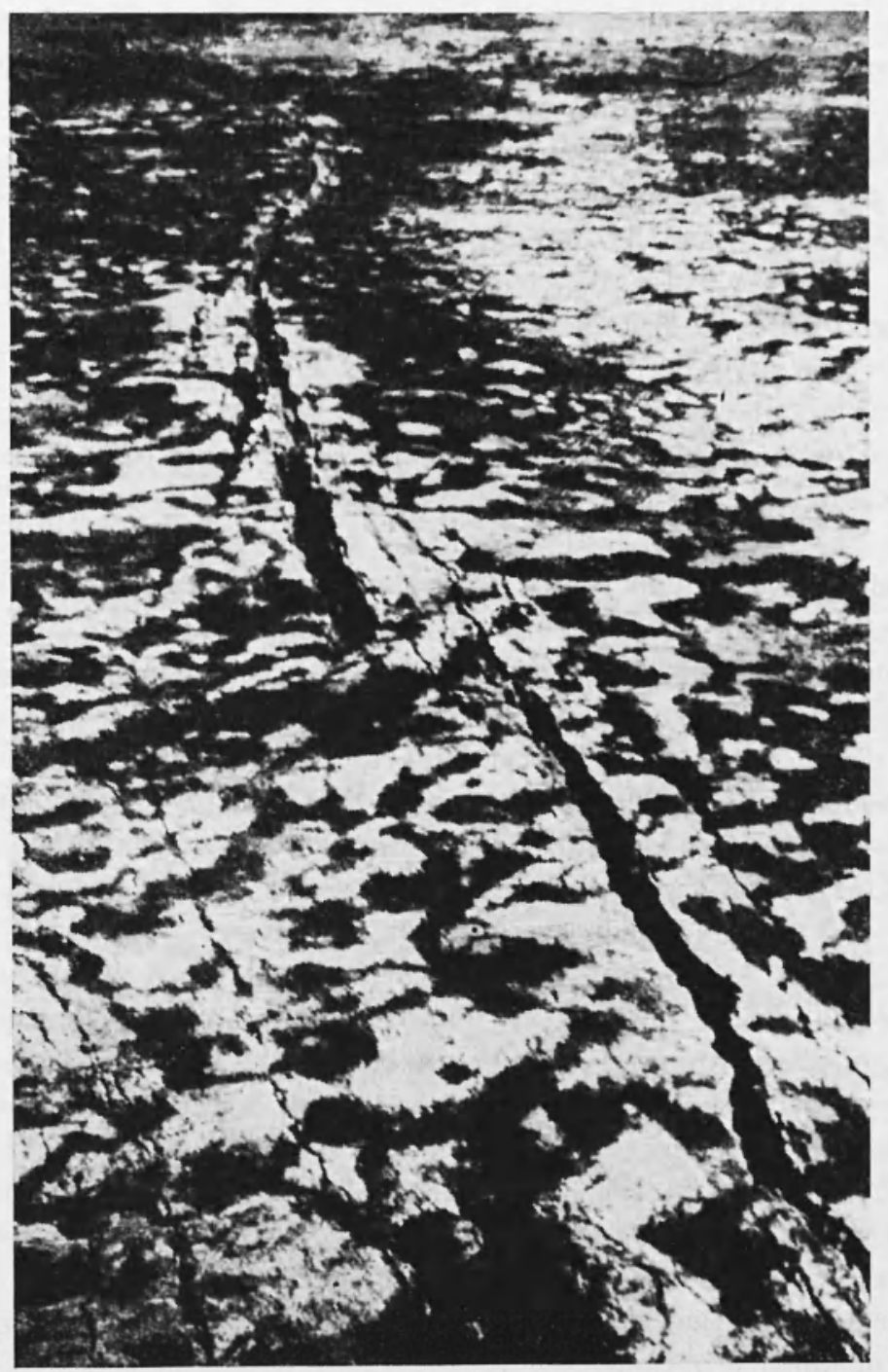

Fig. 15. - In order to comparing with Fig. 14.: vertical fissures in the central graben of Iceland at Hrafnagja. According to geological investigations the central graben is extending at the rate of $3,5 \mathrm{~m} / \mathrm{km} / 1000$ years. The vertical fissures ("gja") parallel the boundary of the median graben of Iceland, and lie along the active earthquake epicentre belt of central Iceland (text and photo were made by Heezen, in: "Continental Drift", edited by S. K. Runcorn, New York, 1962). 
In addition to these the famous mighthy ringmount, discovered by Mariner-4 (frame 11) can be regarded also as a caldera of collapse origin. The Nodus Gordii has a terra-like structure, similar to the Hawaiian calderas. In December, 1971, the NASA released TV pictures of some Martian craters, discovered by Mariner-9. "These do not look very much like impact craters" - commented the photos Dr. H. Mazursky of the US Geological Survey - "but more like complicated terrestrial craters which have experienced successive collapse of their rim walls". In the case of Nix Olympica (the diameter of which is about $500 \mathrm{~km}$ ) the Mariner-9's cameras not only found the possible remains of an ancient volcano but also revealed a volcanic cone inside the great caldera with a diameter of about $64 \mathrm{~km}$. We can see on the enlarged photo of the wall of the Nix Olympica caldera that there is an apparently fresh lava-flow without small impact craters.

On one of the Mariner-9 photos there is a long chasm, probably of tectonic origin. Parallel with it a chain of very small craters can be seen. The members of this chain evidently are of volcanic origin. On the other hand, Heuseler reported that relatively small holes on the Martian surface were also discovered and these formations may be the place of gas-eruptions. The diameter of these holes is varying between some hundred metres and some thousand ones.

Similarly to the Moon's case, there are riverbed-like formations on the Mars, too. If they are not the consequences of the running water, one can suppose that they are signs of underground lava-tubes, the upper (surfacial) part of which collapsed. Similar formations can be found in Mexico.

The most interesting among the volcanic formations of the Mars undoubtedly are the long and by and large parallel rills. Very similar (volcanic) fissures are known from Iceland. Therefore the present author suggests that the respective Martian rills might have been the place of linear eruptions.

\section{CONCLUSION.}

According to our present knowledge the volcanism might have had and having a very important role in the development of terrestrialtype planetary bodies (Earth, Moon, Mars and even Venus as well, since Kosyrev has reported that he found lines in the spectrum of Venus, characteristic of volcanic activity). By other words: volcanism is a cosmical phenomenon. 
EVIDExCES OF ACTIV AND AXCIENT VOLCANISM OX MARS. A REVIEW 503

\section{REFERENCES}

(1) Burgess E., 1972. - Mars Since the Dust Settled. 'New Scientist", 53, 784.

(2) Cameron WV. S., 1971. - Comparative Analyses of Observations of Lunar Transient Phenomena. Greenbelt.

(3) CaPen C. F., 1968. - Green Haze, Gray Clouds, and Rright Spols. JPI, Papers, 606-1.

(4) Capen C. F., 1971. -. Private communication.

(5) Classen J.. 1971. - The Degassing of the Moon. Manuscript.

$\left({ }^{6}\right)$ Davidov V. D., 1970. - See in "Tright Flares on Mars", "Sky and Telescope ", 39, 2.

(7) De Vaucouleurs G., 1971. - Private communication.

(8) DE VAucouleurs G., 1971a. - A Mars Chart for the Mariner Flights. "Sky and Telescope", 41, 5.

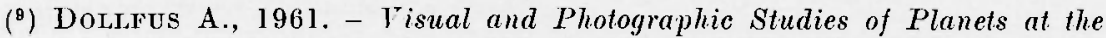
Pic du Midi. "Planets and Satellites", edited by G. P. Kuiper and B. M. Middlehurst. Chicago.

$\left({ }^{10}\right)$ Doldfus A., 1965. - Étude de la Planéte Mars de 19.5t à 1958. "Annales d'Astrophysique ", 28, 4.

(11) Heuseler H., 1969. - Betrachtungen zur Vulkanaktivität auf dem Planeten Lars sowie synoptische Studien atmosphärischer Trübungserscheinungen. "Die Sterne", 45, 7-8.

(12) Heuseder H., 1971. - Der Stand der Mars- und Venusjorchung. "Umschau", Heft 24.

$\left({ }^{13}\right)$ Heuseler H., 1972. - Der Mars ist ein staubiger Planet. "Umschan ". Heft 4.

(14) Katterfeld G. N., 1965. - Volcanic Activity on Mars. NASA TT F-410 (Translation of "Vulkanicheskaya aktivnost' na Marse", Priroda, No. 8).

(15) SAmEki T., 1962. - Some Important Martian Phenomena in 1958. "The Strolling Astronomer ", 16, 11-12.

(16) Sato T., 1971. - Private communication. 